Uniwersytet Mikolaja Kopernika w Toruniu

Katedra Gospodarowania Zasobami Pracy

Hanna Karaszewska

\title{
MIEJSCE I ROLA ROZWOJU ZASOBÓW LUDZKICH W STRATEGICZNYM ZARZĄDZANIU ZASOBAMI PRACY
}

Z a r y s t r e ś c i . Zarządzanie zasobami pracy przeszło daleko idącą ewolucję. W konsekwencji dokonujących się przemian powstała nowa koncepcja strategicznego zarządzania zasobami pracy. Nadała ona nowe miejsce roli kapitału ludzkiego jako podstawowego składnika aktywów przedsiębiorstwa. Rosnąca świadomość potrzeby inwestowania w personel wzmocniła rangę rozwoju zasobów ludzkich w organizacji. Wzmogła również rolę szkoleń jako ważnego narzędzia tego rozwoju. Artykuł stanowi próbę określenia rodzaju strategii rozwoju przedsiębiorstw i wynikających z nich modeli orientacji szkoleniowej przedsiębiorstw. Zaprezentowano w nim również koncepcję organizacji uczącej się z jej podstawowymi cechami: wspólna wizja, mistrzostwo osobiste, modelowe myślenie, zespołowe uczenie się.

S ło w a kluc z o we : strategiczne zarządzanie zasobami pracy, rozwój zasobów pracy, organizacja ucząca się.

\section{WSTĘP}

Postępujące procesy globalizacji, skutkujące zwiększaniem stopnia swobody w przepływie dóbr, usług, kapitału (w tym czynnika pracy), nasilająca się konkurencja i stale zmieniające się, turbulentne otoczenie, wreszcie zaś ekspansja gospodarki opartej na wiedzy tworzą nowe uwarunkowania funkcjonowania podmiotów gospodarczych, realizacji ich strategii i misji. Ekspansja high-tech, postęp w rozwoju technologii informacji i komunikacji, eliminowanie ograniczeń przestrzennych w porozumiewaniu się ludzi i przepływie informacji, 
rozprzestrzeniające się w ślad za ekspansją zagranicznego kapitału zjawisko wielokulturowości potencjału społecznego stwarzają potrzebę adaptowania się do zmian. W walce o zajęcie strategicznej pozycji w rywalizującym świecie wyznaczają również nowoczesnym organizacjom rolę ich kreatora. Tworzą także nowe wymogi pod adresem zarządzania zasobami pracy jako ważnego narzędzia współuczestniczącego w osiąganiu bieżących i długofalowych celów przez podmioty gospodarcze oraz podnoszeniu ich konkurencyjności. Bo właśnie ludzie, wraz z tkwiącym w nich potencjałem, stanowią unikatowy i najtrudniejszy do skopiowania zasób organizacji ${ }^{1}$. Ucieleśniony w nich kapitał ludzki, obok innych aktywów niematerialnych, stanowi jeden z najważniejszych składników kapitału intelektualnego organizacji.

Zarządzanie ludźmi w organizacji przeszło daleko idącą ewolucję - od mieszczącego się w konwencji tylorowskiej podejścia tradycyjnego do strategicznego zarządzania zasobami pracy. Pierwsze z nich, odzwierciedlające typowo instrumentalne podejście do ludzi, nadawało kierownikom rolę strażnika interesów organizacji. Jej realizacja wyrażała się poszukiwaniem dróg przeciwstawienia się interesom pracowników, motywowanych wyłącznie przymusem ekonomicznym, poszukujących dróg minimalizacji nakładu pracy w dążeniu do zabezpieczenia swych fizjologicznych potrzeb. I choć swoista filozofia władzy wydaje się nie przylegać do realiów świata współczesnych organizacji, to przecież jej echa odnajdujemy nie tylko w małych tradycyjnych firmach, ale i dużych organizacjach i instytucjach, w których kierownik usiłuje narzucić pracownikom swoją wizję funkcjonowania i swój autokratyczny styl kierowania. Nie ma w nim miejsca dla działań nakierowanych na podnoszenie potencjału ludzkiego, dla wypełniania konglomeratu, jaki stanowią indywidualne potrzeby i aspiracje, inną niż płaca treścią.

Wraz z wykształceniem się funkcji personalnej w przedsiębiorstwie wykształcały się nowe trendy w jej rozwoju. Od biurokratyzacji wyrażającej się w administrowaniu personelem droga wiodła ku tworzeniu wartości z takimi priorytetami, jak outsourcing, telepraca, równowaga między pracą a życiem, przede wszystkim zaś kapitał ludzki i zarządzanie wiedzą. Dokonująca się ewolucja skutkowała nadaniem szczególnej rangi rozwojowi zasobów ludzkich w organizacji jako integralnej części strategicznego zarządzania zasobami pracy.

1 Warto w tym miejscu przytoczyć słowa P. Druckera: „Stało się truizmem w amerykańskim zarządzaniu, że ze wszystkich zasobów ekonomicznych najmniej sprawnie użytkuje się zasoby ludzkie i że największa szansa poprawy wydajności ekonomicznej tkwi w podniesieniu wydajności pracy ludzkiej. Osiągnięcia przedsiębiorstwa zależą w ostatecznym rachunku od tego, czy potrafi skłonić ludzi do wydajności, czyli do pracy”. Por. Drucker, 1994. 


\section{KONCEPCJA STRATEGICZNEGO ZARZĄDZANIA ZASOBAMI PRACY (ANG. STRATEGIC HUMAN RESOURCES MANAGEMENT)}

Zarządzanie zasobami pracy (ang. Human Resources Management) to „strategiczne i spójne podejście do zarządzania najbardziej wartościowymi aktywami organizacji - pracującymi w niej ludźmi, którzy indywidualnie i zbiorowo przyczyniają się do realizacji jej celów” (Armstrong, 2001). Dążenie do nadania sprawowanej w organizacji funkcji personalnej wymiaru długofalowego i włączanie do procesu zarządzania strategicznego jest przy tym właściwością strategicznego zarządzania zasobami pracy (ang. Strategic Human Resources Management) (Lundy, Cowling, 2000).

Jego specyficznymi cechami są (Armstrong, 2001):

- strategiczna orientacja,

- $\quad$ strategiczne dopasowanie (integracja) - integracja strategii organizacji i strategii ZZP,

- spójność - zintegrowana polityka ZZP,

- traktowanie ludzi jako podstawowy atut konkurencyjny - podstawowy składnik aktywów, czynnik przewagi konkurencyjnej, wyróżnik w otoczeniu,

- $\quad$ traktowanie ludzi jako kapitał - potrzeba inwestowania w ludzi i rozwijania ich potencjału,

- kultura korporacyjna - silna kultura oparta na definiowaniu misji, filozofii, wizji,

- monolityczne stosunki pracownicze - zasoby ludzkie jako zwarty zespół wspólnych wartości, celów, oczekiwań (przeciwieństwo postawy pluralistycznej - interes pracowników nie zawsze jest tożsamy z interesem pracodawców),

- odpowiedzialność kadry kierowniczej - decentralizacja funkcji personalnej poprzez przekazywanie uprawnień menedżerom liniowym.

Tak sformułowana koncepcja ZZL ukierunkowana jest w ostateczności na realizację celów systemowych, których osiagnnięcie wymaga zrealizowania celów bezpośrednich (schemat 1). Biorąc pod uwagę strategiczny aspekt ZZL, kluczowym celem bezpośrednim staje się rozwój potencjału pracy. 


\section{ROZWÓJ ZASOBÓW LUDZKICH \\ JAKO INTEGRALNA CZĘŚĆ STRATEGICZNEGO ZARZĄDZANIA ZASOBAMI PRACY}

Rola człowieka jako twórcy i swoistego akceleratora postępu w organizacji wywodzi się nie tyle z jego zdolności do użytkowania istniejących rozwiązań, ile przede wszystkim do implementacji nowych i ich kreowania (Nelson, Phels, 1996). Zdolność tę wykształca się poprzez inwestycje w rozwój.

Przez pojęcie rozwój zasobów ludzkich w organizacji rozumie się zespół przedsięwzięć służących wzbogacaniu wiedzy, rozwijaniu umiejętności i zdolności, kształtowaniu postaw, zachowań i motywacji, doskonaleniu kondycji fizycznej i psychicznej pracowników. Przedsięwzięcia te w ostateczności prowadzą do wzrostu efektywności organizacji oraz do podnoszenia wartości rynkowej zasobów pracy (Pocztowski, 2005).
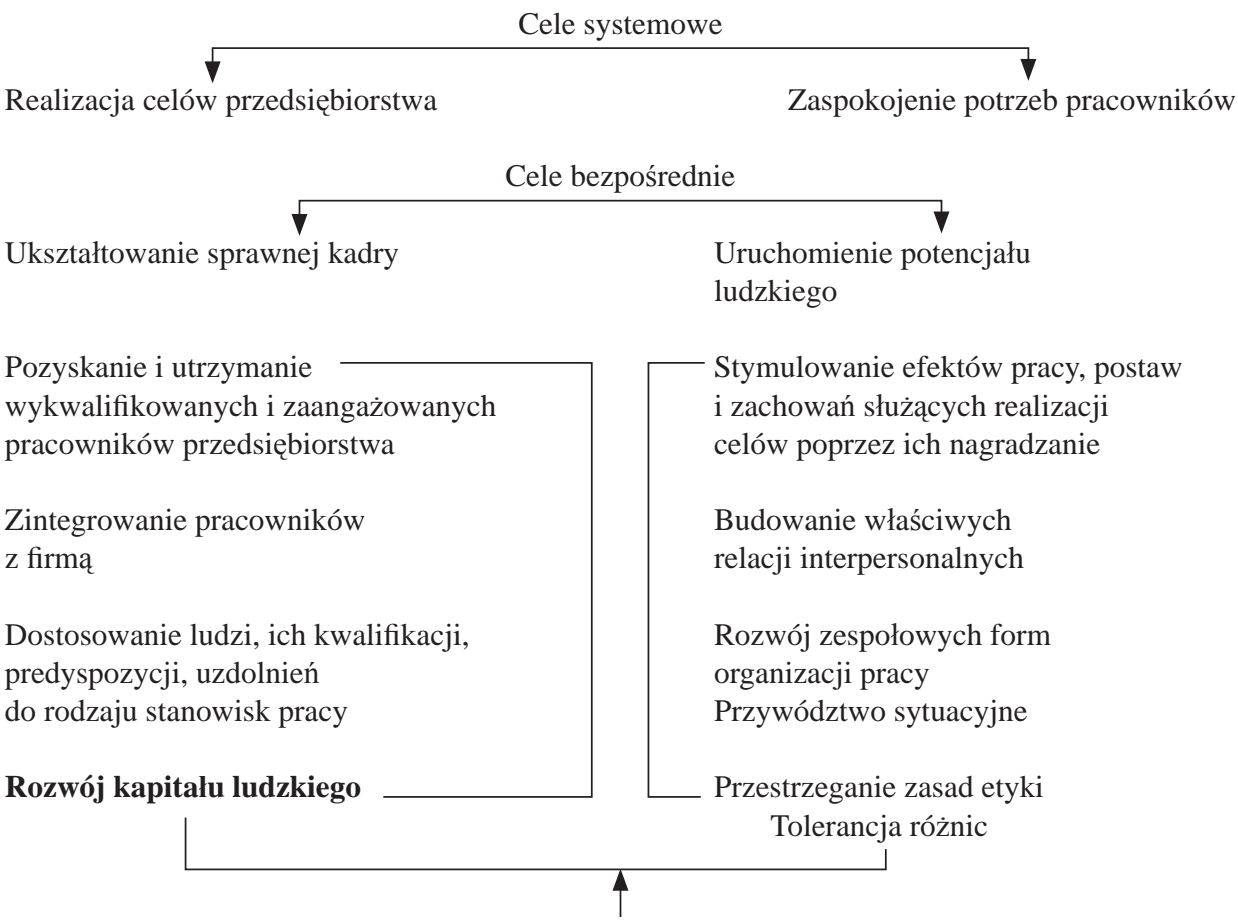

Współtworzenie warunków równowagi organizacyjnej (godzenie interesów stakeholders)

Schemat 1. Cele strategicznego zarządzania zasobami pracy

Źródło: opracowanie własne. 
Rozwój to tworzenie przez organizację warunków kształtowania i doskonalenia kapitału ludzkiego (połączenie wiedzy, umiejętności, innowacyjności i zdolności) dla realizacji jej celów i w odpowiedzi na potrzeby i aspiracje pracowników. To wreszcie działanie nakierowane na podnoszenie poziomu kompetencji ${ }^{2}$ rozumianych jako ogół atrybutów i wyrażających je procesów (zachowań) generujących pozycję jednostki w organizacji, warunkujących sprawność jej działania w różnych perspektywach czasowych. Działania te mieszczą się w obszarze szkolenia i doskonalenia zawodowego, przemieszczeń pracowników w organizacji, zintegrowanych indywidualnych i organizacyjnych planów kariery, strukturyzacji pracy (celowe kształtowanie treści i warunków pracy na stanowisku/grupie stanowisk pracy). Miejsce rozwoju kapitału ludzkiego w strategii organizacji prezentuje schemat 2.

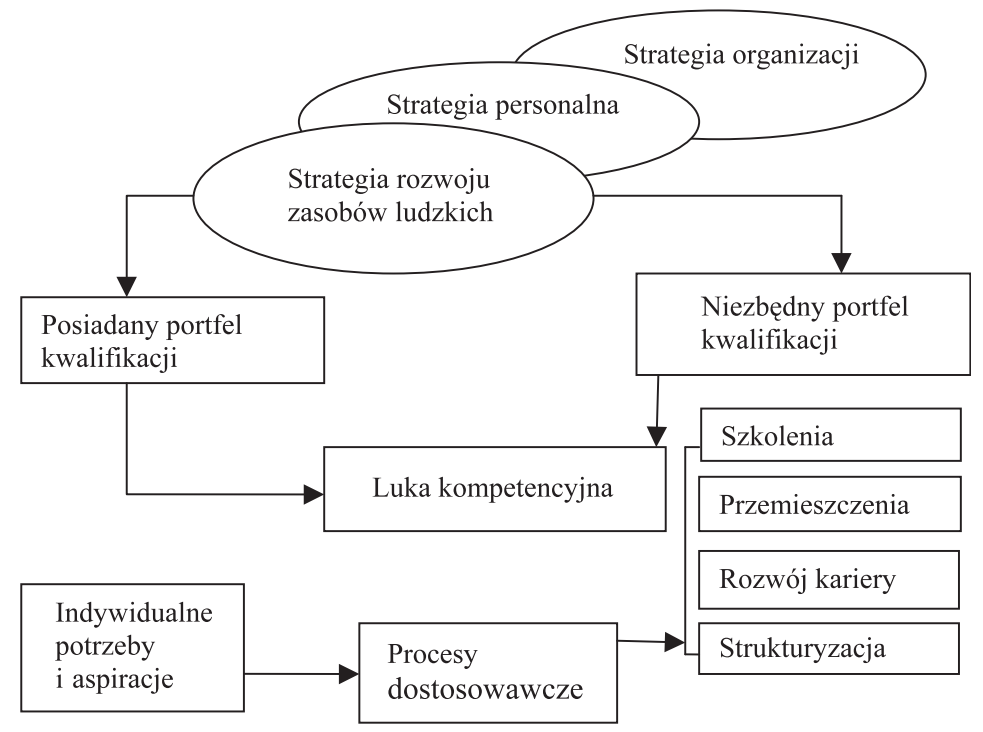

Schemat 2. Miejsce strategii rozwoju zasobów pracy w strategii organizacji

Źródło: opracowanie własne na podstawie literatury przedmiotu.

2 Samo pojęcie kompetencji nie jest rozumiane w literaturze jednoznacznie. W jego interpretowaniu można wyróżnić podejście behawioralne, prakseologiczne, atrybutowo-procesowe. Pierwsze z nich kładzie nacisk na zachowania właściwe osobom o różnym stopniu skuteczności (Boyatzis, 1982), drugie podkreśla umiejętność i skuteczność wykorzystania posiadanych kwalifikacji i wiedzy (Fletcher, 1991). Podejście atrybutowo procesowe zaprezentowano w opracowaniu. Jest ono również zbieżne z postrzeganiem kompetencji przez Boyatzisa (1982) określającego je jako „potencjał istniejący w człowieku, prowadzący do takiego zachowania, które przyczynia się do zaspokojenia wymagań na danym stanowisku pracy w ramach parametrów otoczenia organizacji, co z kolei daje pożądane wyniki”. 


\section{STRATEGIE ROZWOJU ZASOBÓW LUDZKICH}

W praktyce zarządzania zasobami pracy spotyka się różne podejścia do rozwoju zasobów ludzkich w organizacji. Są one pochodną strategii organizacji i jej strategii personalnej. Związki między strategią ZZL ${ }^{3}$ a strategią rozwoju zasobów pracy prezentuje schemat 3 .

Kryteria wyodrębniania strategii ZZL

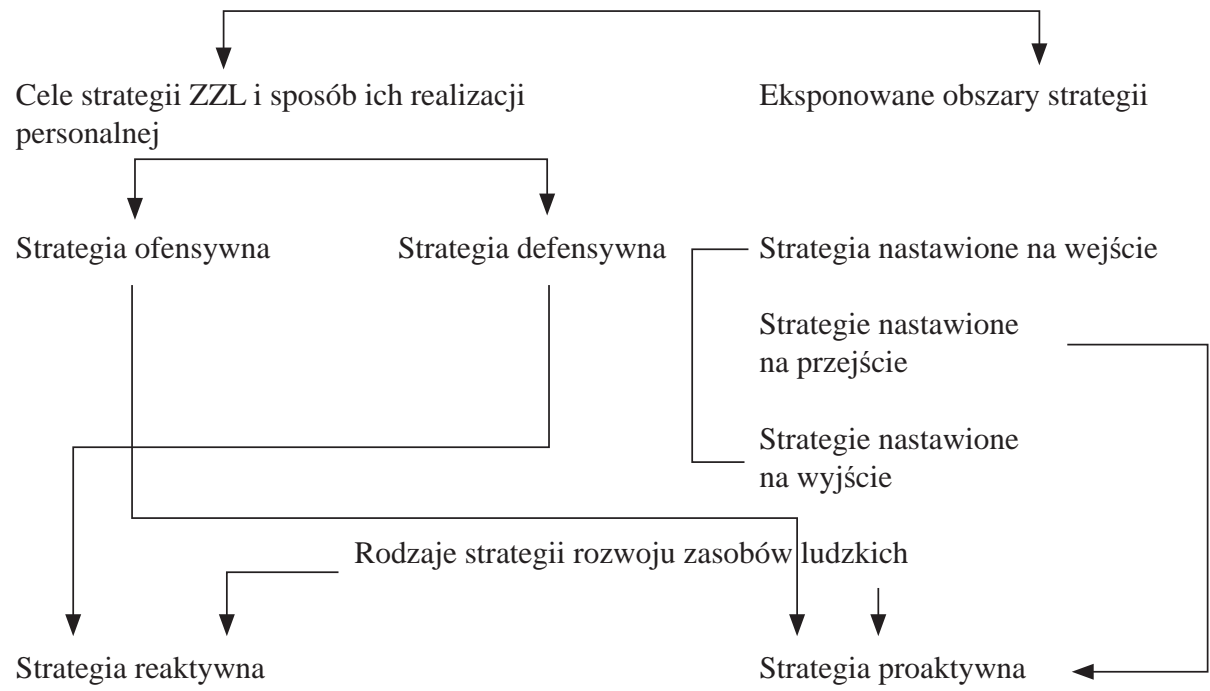

Schemat 3. Kryteria wyodrębniania strategii ZZL, jej rodzaje oraz związki ze strategiami rozwoju zasobów ludzkich

Źródło: opracowanie własne.

Strategie ofensywne dotyczą przedsiębiorstw dynamicznie rozwijających się, wymagających od swoich pracowników wsparcia tego rozwoju (kreatywności, innowacyjności, dużej tolerancji ryzyka). Nastawienie na osiąganie efektów ma wymiar długofalowy. Strategie tego typu generują prowadzenie celowej polityki nakierowanej na tworzenie w przedsiębiorstwie odpowiedniego zasobu wiedzy i umiejętności jako podstawowego atutu konkurencyjnego przedsiębiorstwa. Przedsiębiorstwa podejmują działania w celu pozyskania młodej, wykwalifikowanej kadry o dużym potencjale rozwojowym oraz intensywnie inwestują w rozwój.

3 W wyodrębnianiu rodzajów strategii ZZL wykorzystano klasyfikację Fischera (1989), Listwana (2002) oraz Croziera (1993). 
Na drugim biegunie sytuują się przedsiębiorstwa prowadzące defensywną strategię ZZL, nastawione na bieżące, wymierne w sensie ilościowym wyniki, dążące do minimalizowania zakresu wpływu otoczenia dla zachowania względnej stabilności. Nastawione na rekrutację wewnętrzną koncentrują się raczej na własnym personelu, podejmując przedsięwzięcia służące uzupełnianiu luk kompetencyjnych zidentyfikowanych w drodze systemowej oceny efektów pracy/kompetencji. Często są przedsięwzięciami ex post, stanowiącymi reakcję na problemy organizacji wynikające z braku pracowników o odpowiednim potencjale (strategia reaktywna).

Przedsiębiorstwa wykorzystujące model sita nie podejmują aktywności w obszarze rozwoju personelu, przerzucając na pracowników podejmowanie przedsięwzięć służących utrzymaniu ich pozycji konkurencyjnej poprzez inwestowanie we własny rozwój.

Powyższe podejścia mieszczą się w tradycyjnym postrzeganiu rozwoju ludzi w organizacji. „Nowoczesne, strategiczne podejście do rozwoju zasobów ludzkich zakłada zintegrowane podejście do kreowania uczenia się w organizacji poprzez jasne określenie misji firmy w zakresie zarządzania nimi, dobór celów wspierających tworzenie wartości w organizacji, ukształtowanie warunków sprzyjających realizacji tych celów, rozwijanie narzędzi stymulujących procesy uczenia się na poziomie jednostek, zespołów, organizacji” (Pocztowski, 2005).

\section{SZKOLENIA JAKO INTEGRALNA CZĘŚĆ ROZWOJU ZL - EWOLUCJA PODEJŚCIA}

Podejścia do rozwoju ZL generują różne modele orientacji szkoleniowej przedsiębiorstw (Andrzejczak, 2005):

- model tradycyjny - szkolenia nakierowane na potrzeby stanowisk pracy, dobór tematyki szkoleń pod kątem uzupełniania luk kwalifikacyjnych, preferowanie tradycyjnych metod nauczania,

- model rozwojowy - orientacja długofalowa (ukierunkowanie na zmiany oraz efekty innowacyjne) $\mathrm{z}$ preferowaniem tradycyjnych metod szkolenia,

- model nieformalny - wykorzystanie metod szkolenia on the job - typu „siedząc obok Nelly”, przyuczenie w działaniu przy nastawieniu na dostosowanie kompetencji do wymagań stanowisk pracy,

- model innowacyjny - wspieranie form i metod kształcenia dla kreowania nowych pomysłów, tworzenia nowych wartości, tworzenie klimatu uczenia się jako integralnej części pracy zawodowej.

Ostatnia z filozofii szkoleń kreuje model organizacji uczącej się. 


\section{ORGANIZACJA UCZĄCA SIĘ}

Organizacja inteligentna to taka, która wspiera proces uczenia się, podlegając jednocześnie nieustającym zmianom, której członkowie rozwijają swój potencjał indywidualnie i zespołowo, aby osiągnąć cel, na którym im zależy, organizacja, w której dominuje kultura uczenia się.

Założeniami leżącymi u podstaw organizacji uczącej się jest przekonanie, iż:

- $\quad$ uczenie się jest wartością

- uczenie się jest procesem ciągłym;

- łatwiej jest utrzymać wyniki, jeśli dzieli się je z innymi ludźmi.

Cechami organizacji inteligentnej są (Senge, 2000):

- Wspólna wizja - prowadzi ludzi do doskonałości i wzajemnego uczenia dla wypełnienia synergicznych celów własnych i organizacji, ludzie wspierają to, czego sami pragną.

- Mistrzostwo osobiste - dążenie do tego, by w zakresie swych działań być mistrzem generuje dążenie do ciągłego rozwoju. Organizacja natomiast musi dbać, by dążenie to miało szanse na realizację.

- Zespołowe myślenie - dążenie do wspólnego odkrywania zasad, rozwiązywania problemów, podejmowania decyzji.

- Myślenie systemowe - umiejętność dostrzegania wzajemnych powiązań między elementami.

- Dostrzeganie, że problemy nie powstają gdzieś tam i z czyjejś winy, lecz że sami je współtworzymy („trzeba widzieć i drzewa, i las”).

- Modelowe myślenie - skierowanie uwagi na własne założenia i świadome wpływanie na nie w taki sposób, by przyczyniały się do rozwoju osobistego i organizacyjnego (,prawdziwych odkryć dokonasz dzięki nowym oczom, a nie kontynentom”).

Przejście od tradycyjnego szkolenia do organizacji uczącej się ma znaczenie strategiczne. Umożliwia bowiem przedsiębiorstwom tworzenie nowych wartości w postaci rynków, produktów i zysków (Rybak, 2000). 


\section{PODSUMOWANIE}

Strategiczne zarządzanie zasobami pracy kreuje nowe podejście do rozwoju kapitału ludzkiego jako ważnego atutu konkurencyjnego organizacji. Generuje przejście od tradycyjnych szkoleń w kierunku stymulowania procesów ciągłego uczenia się jednostek, zespołów organizacji. Tylko takie podejście włącza proces zarządzania zasobami pracy w kreowanie nowych wartości.

W większości firm w Polsce nadal obowiązuje tradycyjny model orientacji szkoleniowej. Choć widoczne są nowe tendencje (wyraźne dostrzeganie roli osobistego zaangażowania się w proces uczenia), to wciąż jeszcze dotyczą one metod, nie zaś celów czy filozofii szkoleń (Andrzejczak, 2005).

\section{LITERATURA}

Andrzejczak A. (2005), Od szkolenia do organizacyjnego uczenia się, [w:] Borkowska S. (red.), Przyszłość pracy w XXI wieku, IPiSS, Warszawa.

Armstrong M. (2001), Zarzq̨dzanie zasobami ludzkimi, Dom Wydawniczy ABC, OE, Kraków.

Boyatzis R. (1982), The Competent Meneger, Wiley, New York.

Crozier M. (1993), Przedsiębiorstwo na podsluchu. Jak nauczyć się zarzq̨dzania postindustrialnego, PWE, Warszawa.

Drucker P. (1994), Praktyka zarzadzania. Nowoczesność, Czytelnik-Akademia Ekonomiczna w Krakowie, Kraków.

Fischer C. (1989), Current and Recurrent Challenches in HRM, „Journal of Management”, No. 15.

Fletcher S. (1991), NVQS Standards and Competence, Kogan Page, London.

Listwan T. (2002), Modele i składniki strategicznego zarzqdzania kadrami, [w:] Listwan T. (red.), Zarzadzanie kadrami, CH Beck, Warszawa.

Lundy O., Cowling A. (2000), Strategiczne zarzq̨dzanie zasobami ludzkimi, Kraków.

Nelson R. R., Phels S. (1996), Investment In Humans, Technological Diffusion and Economics Groth, „American Economic Review”, vol. 56.

Pocztowski A. (2005), Strategiczne aspekty rozwoju zasobów ludzkich, [w:] Borkowska S. (red.), Przyszłość pracy w XXI wieku, IPiSS, Warszawa.

Pocztowski A., Wiśniewski Z. (red.) (2004), Zarzqdzanie zasobami ludzkimi w warunkach nowej gospodarki, Oficyna Ekonomiczna, Kraków.

Rybak M. (2000), Zintegrowane uczenie się organizacji a zarzq̨dzanie zasobami ludzkimi, [w:] Senge A. P. M., Piqta dyscyplina. Teoria i praktyka organizacji uczacych się, ABC, Warszawa.

Senge A. P. M. (2000), Piqta dyscyplina. Teoria i praktyka organizacji uczqcych się, ABC, Warszawa. 


\section{THE ROLE OF THE HUMAN RESOURCES DEVELOPMENT IN THE STRATEGIC RESOURCE MANAGEMENT}

A b stra ct. Human Resources Management went through significant evolution. The newly conceived idea of strategic management in human resources is the consequence of past and coming changes. Human capital became the foundation for the business. Businesses realized the importance of strengthening and developing human capital in their organizations. Training programs, therefore, become the most important tool in this development. The article further defines the strategies for enterprise development and the resulting models of training programs. It presents the concept of ongoing learning in the organization centered on a common vision, personal championship, model thinking, and team learning.

K e y w o rd s : strategic human resources management, human resources development, studying organization. 